\title{
Negotiations between Muslims and Crusaders at the Crusader invasion of the Levant (489-492 BC/1096-1099 AD)
}

\author{
D. Ghassan Mahmoud Washah* \\ Head of the Department of History and Archeology at the Islamic University of Gaza
}

"Corresponding Author: D. Ghassan Mahmoud Washah, Head of the Department of History and Archeology at the Islamic University of Gaza

\begin{abstract}
Political negotiations are an integral part of the conflict between adversaries during periods of war and peace. At the time of the Crusader invasion of the Levant during the first crusade, many rounds of negotiations took place between the invading Crusaders and the Muslims who owned the land. These negotiations resulted in alliances, treaties and surrender of cities and fortresses. The negotiations reflect the weakness experienced by the Muslims. The most famous of these negotiations took place with the Fatimids and the princes of the Seljuk Shami cities. The most important negotiations focused on Antioch and Jerusalem.

The Crusaders spread panic and committed massacres and worked to spread the division among the Muslims to divide each of them separately and weaken their front. The Muslims also failed to defend their cities and strongholds and followed the policies of zeal and proximity to the Crusaders to prevent their evil. They also proceeded to provide them with supplies and guides. In their initiative to request the alliance with the Crusaders against the Seljuks, but the Crusaders betrayed them and broke their covenant with them.
\end{abstract}

\section{INTRODUCTION}

The Islamic nation before the Crusader invasion of the Levant suffered from chaos and disintegration and internal conflicts, which weakened and disintegrated it, the entities of the Islamic Ummah dismantled in front of the Crusader invasion. Instead of making unity to face the Crusaders, most of the princes of these entities sought to negotiate with the occupiers invaders. To reach an agreement with the occupiers against their Muslim brothers. Negotiations were talking about the suffering of the Crusaders model of the comic negotiations and absurd loss of responsibility, which resulted in the loss of Palestine and the entire coast Shami; and the massacre of its people and its inhabitants.

\subsection{The Importance of Studying}

- The scarcity of serious academic studies that dealt with the subject despite its importance.

- Demonstrating the situation of the Islamic Ummah before the Crusader invasion of the Levant and Palestine and the impact of negotiations between the two sides.

- To highlight the relationship of weakness and disintegration among Muslims on the terms and strategies of negotiations with the Crusader occupier.

- To highlight the strategies of the crusaders in following the policy of agreements of parity with the Islamic entities in the post-occupation of the Islamic land with the aim of creating a security zone for the Crusader entities.

\subsection{Study Approach}

The researcher followed the historical approach in the study.

\subsection{Divisions of the Study}

The study has been divided into six main points and a conclusion and proved with the most important sources and references.

\section{First: The Status of the Levant and its Islamic Surroundings When the First Crusade Came}

Palestine, as the greatest holy land for Christians, they were going to it to visit their holy sites, and to perform the rituals of pilgrimage and rituals of worship, and that since the times before the Islamic conquest of Palestine, and continued after the Islamic conquest under the pact of 
Omar $^{(1)}$ of the faithful Omar bin Khattab with the Christians of Jerusalem. The successive Islamic authorities allowed establishing shelters for the care of pilgrims and Christian visitors. ${ }^{(2))}$

The Levant and its environs were divided politically into small entities. The relations between these entities were hostile, and they were torn apart, divided, quarreled and fought for power and influence ${ }^{((3))}$. The most important of these entities are:

The Emirate of Aleppo ${ }^{(4)}$ : ruled by Radwan ben Titch Seljuki ; the Kingdom of Damascus ${ }^{(5)}$ : ruled by Dokak bin Tesh Seljuki ; the Principality of Antioch ${ }^{(6)}$ : ruled by Yaghi Sian ${ }^{(7)}$; the Principality of Shizer ${ }^{(8)}$ : ruled by Abo Al Asaker Soltan bin Monkith $^{(9)}$; the Principality of trablus ${ }^{(10)}$ : ruled by Al Arabi Abo Ali Fakher Al Molok bin Ammar ${ }^{(9)}$; the Principality of humus ${ }^{11}$ : It is ruled by Janah Al Dawla bin Malaeb ${ }^{(12)}$; the Principality of Jerusalem: ruled by the princes of Sakman and Ilghazi

The sons of Arteq; the Euphrates Island region ${ }^{13}$ was suffering from bloody conflicts among its local rulers, who fluctuated in their loyalties. They alternated in allegiance to the Seljuks sometimes and to the Fatimids at other times. It was not loyalty to religion, but to their interests ${ }^{14}$.

In addition to the political division, the region suffered from a religious split of political dimensions, which is the existence of two caliphs: Abbasid following the Sunni sect in Baghdad; and a Fatimid one with following the Shiite sect in Cairo, knowing that the position of succession in both successions was either ceremonial or symbolic, or as some historian call it "spiritual power". Whereas the real powers were in the hands of the minister or the so-called "temporal authority". The two caliphs suffered a long time from the internal conflict between the spiritual and temporal authorities in

(1) Pact of omar 15 BC/638 AD: Omar bin Al khattab pledged to The Christians of Jerusalem when he controlled it to secure them and their churches and their concerns. Al Thahabi, The History of Islam (part3/162),Ibn Khaldun, History (part2/543-545).

${ }^{(2)}$ Hateet , issues (page 98-99).

(3) Abo Saed,The Islamic Front (page 69-70), Sharab, Al Mada'in Al Falastenia (part1-209), Yousof, The Unity During The Crusade.(page13), Conflict between Islamic Forces (page9-14).

(4) Aleppo: A city located in the north of the Levant, known for its robustness and good weather. Al-Hamwi, Dictionary of Countries (part 2/ 282); Al-Maqdisi, Ahsan Al Takaseem.

(5) Damascus: It is the largest city of the Levant, and it is considered the historical capital of it. It is situated on flat land surrounded by mountains from all sides and is famous for its good fruits. Al-Hamwi, Dictionary of Countries (part 2/463).

(6) Antioch: A city located in the north of the Levant. It is considered one of the stables for its proximity to the sites of confrontations with the Byzantines and Romans, which is one of the pillars of the country and its mothers, described as good and sweet, Yaqoot, Glossary of Countries (part 1 / 266).

(7) Yaghi Sian: A Turkmen military commander who ruled Antioch and inherited from his father under the command of Tych ibn al-Arslan, died in 491 BC / 1098 AD. Aldawadar, treasure Alderar (part 6/430); Al THahabi, the history of Islam (part 33/29).

(8) Shizer: The village in the Levant near Ma'arat al-Nu'man, in the middle of the Jordan River. Yaqoot, Dictionary of Countries (part3 / 383).

(9) Sultan bin Munqadh: the owner of Shizar, and was working on the expansion of his kingdom, and included Msaif by buying it from the owner. Al Safadi, Alwafi Bi Al Wafeat (part 27/252).

${ }^{(8)}$ Tripoli: The city in the Levant overlooking the Mediterranean Sea, between it and Damascus ninety miles. Abu al-Fida, Tqweem Al Boldan (part 253).

${ }^{9}$ Ibn Ammar: the owner of Tripoli and known of savvy and wise, and grabbed the Crusaders grabbed Tripoli from him in the year $502 \mathrm{BC}$, and joined Tagtkin and became one of his men. Al THahabi, Seyar Alam Al Nobala (part 19 / 311-312).

${ }^{11}$ Homs: It is a famous, large, fortified and picturesque city, located halfway between Damascus and Aleppo. Yakoot, Dictionary of Countries (part 2/302).

${ }^{(12)}$ Guanmeh, Treaties of Reconciliation (part 15)

${ }^{3}$ The Euphrates Island: is the region between the Tigris and the Euphrates Rivers. It is called the island because it is located between them. It is bordered by the Levant from the west, Faris from the east, from the south Iraq and from the north Asia Minor. With large cities and impregnable fortresses. Yakoot, Glossary of Countries (part 2 / 143).

4 Mayer, The History of the Crusades (part 1 / 99-100); Abu Sa'id, The Front (page 60-67); Al Matwe, The Crusades (p. 17), Al Mada'in Al Falastenia (part1/210).

5 Al Matwe, The Crusades (page 15-17); Abu Sa'id, The Islamic Front (page 20-33); Sharab, Al Mada'in Al Falastenia (page1 / 209-210). Zian, The Conflict between the Islamic Forces (page 32-37). 
each succession. The region also suffered from the division and dispersion of the largest Islamic force at that time, which is the Seljuk. ${ }^{15}$ The problems of the region are the main reason for the Crusaders' victory in the first Crusade ${ }^{16}$.

It is noteworthy that in the midst of the Crusade invasion of the Levant, there were modest efforts by Muslim scholars to try to unify the Islamic sect. The embassies of scholars moved from the Abbasid caliph $\mathrm{Al}$ Mostatheer Billah ${ }^{17}$ to the princes of the Levant to urge them to unite and discard disputes. Some scholars also went to the Abbasid Caliph to urge him to intervention to make things good with the Shaman princes. ${ }^{18}$

\section{THIRD: THE FIRST CRUSADE AND ITS ORIENTATION TO THE ISLAMIC MASHREQ}

The first Crusade was formed as a result of calls from the Byzantine Empire ${ }^{19}$ to help it fight the Seljuks of Rome after its defeat in the battle of Malakirid in $463 \mathrm{BC} / 1071 \mathrm{AD}^{20}$. Pope Gregory VII ${ }^{21}$ called for a crusade against the Levant to recover Christian holy sites and to expand his powers to Church of Constantinople ${ }^{22}$, in $467 \mathrm{BC} / 1074 \mathrm{AD},{ }^{23}$ and the researcher should exclude considering the first crusade and the outbreak of the crusader spirit in European circles as a direct echo of the location of Malakird. The Byzantines often faced the invasions of Muslims, and often asked for help from the Pope of Rome without receiving any response, the researcher believes that The Crusader sect was formed as a result of other social, economic and political reasons, and this is confirmed by Western sources. ${ }^{24}$

The campaign was formed by European forces, most of them French and German ${ }^{25}$, and went to Constantinople in $489 \mathrm{BC} / 1096 \mathrm{AD}^{26}$. The Byzantine Emperor Alexis Commenin ${ }^{27}$ demanded that these forces owe him allegiance and obedience. After rejection, hesitation and rebellion by the Crusaders it was agreed that they would be loyal to him. All the countries that the Crusaders get back from Muslims were given to him and subjected to Byzantine rule before being conquered by Muslims. ${ }^{28}$

15 The Seljuk state:An Islamic state founded by Turkish groups in 429 BC/1137AD in Central Asia.The Seljuk state was divided after the death of Malakshah in 484 BC/1092AD to several warring countries.They are:

Seljuks Persia and Iraq, The Seljuks of the Romans in Asia Minor were headed by the Qarj Arslan,as well as the Seljuks of the Levant, divided between themselves between Radwan and Dakak,the sons of Tich,who rule Aleppo and Damascus.Al THahabi, The History of Islam(part 32-20)Ibn Kather, The beginning and the end (part 12/54-56);Shorab, Al Mada'in Al Falastenia (part 1/209-210).

${ }^{16}$ Abu Sa'id, Islamic Front (page 69-70); Al Zobaie, Arab Resistance (page 272), Meyer, History of the Crusades (part 1/ 99); Shorab,Al Mada'in Al Falastenia (part 1/ 210).

17 Al Mostather Billah: Abbasid caliph who ruled during the period (487-512 BC / 1094-1118 AD). Suyuti, History of the Caliphs (page 303-306).

18 Ashour, Adwa Jadeda (page 27); the most famous of these scientists: Abdul Wahid bin Rizkullah and Abdul Aziz bin Ali bin Mohammed, a scholar of the fifth century. Hussein, Some Embassies (page363-364).

19 The Byzantine Empire: It was a great Christian state established in 234 BC / 395 AD in Eastern Europe, South-West Asia, and North-East Africa. It took Constantinople as its capital and ended in 856 BC / 1453 AD. Durant, The Story of Civilization (part 12 / 5-18).

${ }^{20}$ Battle of Malzkird: A major battle broke out between the Seljuks led by Alp Arslan and the Byzantines led by Emperor Romanus, resulting in the defeat of the Byzantines and the capture of their emperor, and subjugating Asia Minor to rule the Seljuks. Ibn al-Atheer, Al-Kamil (part 6/626); Ibn Al Emad: Shatharat Al Dahab (part 5 / 262); Al Souri, the Crusades (part $1 / 83-85$ ).

${ }^{21}$ Gregory VII: He is the Pope of the Roman Catholic Church in Rome during the years 465-477 BC / 1073-

1085 AD. Durant, The Story of Civilization (part 14/387).

${ }^{22}$ Constantinople: A great city in the Bosphorus, known today as Istanbul, Turkey. Yakoot, Dictionary of Countries (part 4 / 347).

${ }^{23}$ Zaburov, the Crusaders in the East (page 41); the Mutawie, the Crusades (page 30); Al Ganzuri, the Roman attacks (page 189).

${ }^{24}$ New Lights (part 20/21).

${ }^{25}$ Al Souri, the Crusades, (part 1/ 83-85);Zaburov: Crusaders in the East (page 31), Meyer, History of the Crusades (part 1 / 24, 91-93) Al-Mutawi, the Crusades (page30).

${ }^{26}$ Al Souri, the Crusades(part1/145).

27 Alexis Komnin: Emperor of the Byzantine Empire during the period 473-511 BC / 1081-1118 AD. The Arabic Encyclopedia (3/342).

${ }^{28} \mathrm{Al}$ shatri, the history of the campaign (page 45). 
The Crusader forces went to the Muslim countries, demonstrating their strength and the number of their soldiers and what increased their confidence is: the sequential victory; and separating the Muslims and their conflicts with each other. Under these conditions, the policy of negotiations was not on the agenda of the leaders of the campaign, but making policies of determination, committing massacres and imposing surrender over the Islamic countries. ${ }^{29}$

Asia Minor ${ }^{30}$ was the land route of the Crusaders from Constantinople to the Levant and was subject to the rule of the Seljuks of the Romans ${ }^{31}$. The Crusaders entered Asia Minor, achieving many victories over the Seljuks, who only noticed this danger too late. The Seljuks lost much of Asia Minor in their defeats against crusaders. This country was handed over to the Byzantine Empire in accordance with the agreement with its empress ${ }^{32}$, although the Seljuks of the Romans were in unity and military preparation appropriate to change the course of events altogether. ${ }^{33}$

The expedition moved from Constantinople to the depths of Asia Minor and surrounded Nicaea ${ }^{34}$. After a fierce resistance from the Seljuks, the representatives of the Byzantine Emperor negotiated with the owners of Nicaea to leave the city safely on 7 Jumada II 489 BC (26 July 1096 AD). The deal successes without knowing the Crusader forces that besieged the city. ${ }^{35}$

It is clearly from the above the difference and the discredit in the Byzantine-Crusader area. At the time Crusaders are surrounding Nicaea to open it forcibly, a Byzantine delegation goes to Nicaea, and their Islamic protectorate is forced to surrender without the knowledge of their crusader allies. It is clear that both the Crusaders and the Byzantines have contradictory goals of their war against Muslims, and each of them tries to gain without his partner.

The Crusader forces took control of the Seljuk cities of Asia Minor, using the military determination sometimes, using tricks and deception, and sometimes using the Christians inside these cities to facilitate their conquest and control, such as the cities of Tel Basher ${ }^{36}$ and Tartus ${ }^{37}$ and the Citadel of Arata $^{38} .{ }^{39}$

\section{Fourth: Negotiations DURING THE SIEGE OF ANTIOCH ${ }^{40}$}

Antioch is the northern gate of Sham from Asia Minor. The Crusader forces arrived and besieged it ${ }^{41}$, and there were many Islamic-Crusader negotiations that took place, the most important is:

\footnotetext{
${ }^{29}$ Atea, the history the Crusades (page 87), Qasem, the Crusades (page101).

30 Asia Minor: The region known geographically as the Anatolian peninsula and known historically as the country of the Roman, known as the policy of the state of Turkey, which is mountainous and coastal areas, with many rivers, bordered to the east by Persia, Azerbaijan and Armenia, bordered to the west and south Mediterranean Sea, And south of the Levant and Iraq, and the most important cities of Constantinople (Istanbul). Al-Totaili, Journey (page. 10); Ibn Battuta, Journey (part2 / 155-157)

31 Abu Said, The Islamic Front (page 19, 33); Al Sheikh, The Age of the Crusades (page 123); Zaburov, Crusaders in the East (page 76).

32 Abo Al Feda, History (part2/158). Al Mokhtasar (part 2/210).Ibn Kaldun, History (part 4/85), Mayer,The History of the Crusades (part1 /94).

${ }_{33}$ Abo Saed, The Islamic Front (page 67-68).

${ }^{34}$ Nicaea: A city located in Asia Minor, southwest of Constantinople, surrounded by mountains, with ten fortresses, and a distance of ten miles from the sea. Yakoot, Dictionary of Countries (part 5/333); son of Khardabah, Al Masalek Wa Al Mamalek (page 106).

${ }^{35}$ Al Shatri, the history of the campaign (page 46-47), Al Souri the Crusade(part 1/221), Todipod: History of the Journey, (page 111); Meyer, History of the Crusades (part 1/ 94).

${ }^{36}$ Tal Basher: A fortified castle and a large village, located north of Aleppo, and most of its inhabitants are Christians. Yakoot, Dictionary of Countries (part 2/40).

${ }^{37}$ Tarsus: A city in the suburbs of Damascus, located between Aleppo, Antioch and the Roman lands. Yakoot, Dictionary of Countries (part 4/28).

${ }^{38}$ The Fortress of Artah: An Immortal Fortress from the Works of Aleppo. Yakoot, Dictionary of Countries (part 1/ 140).

${ }^{39}$ Abo Al Fedaa, Al Mokhtasar (part 2/220), Al Dawader, Kanz Al Dorar (part 6/465), Zaburov, Crusaders in the East (page 76/82).

${ }^{40}$ Antioch: A city located in the north of the Levant. It is considered one of the stables for its proximity to the sites of confrontations with the Byzantines and Romans, which is one of the pillars of the country, described as good and sweet, Yakoot, Glossary of Countries (part 1/ 266).

${ }^{41}$ Al Souri, the Crusade (part 1/283), Qaseem, The Crusade(page 103).
} 


\subsection{Negotiations of the Crusaders with the Fatimids to Allay against the Seljuks}

The Fatimids sent an embassy to the Crusaders who besieged Antioch, offering them assistance and cooperation to face the Seljuks, which was already agreed upon, The Fatimids supplied the Crusaders with equipment, ammunition and supplies to complete the siege of Antioch ${ }^{42}$. The Fatimid delegation set up alongside the Crusader forces which besieged Antioch as a form of support to them ${ }^{43}$.During their negotiations, the Fatimids offered the Crusaders a proposal to extract the Levant from the Seljuks, and to divide it to be the Crusaders take north of the Levant, and the Fatimids take south of the Levant, including Palestine and Jerusalem ${ }^{44}$, and the Crusaders become a barrier between the Fatimids and Seljuks ${ }^{45}$. Then the Fatimid delegation returned to Cairo accompanied by a delegation of crusaders to meet the leadership of the Fatimid state to complete negotiations on the details of the agreement, alliance and cooperation. ${ }^{46}$

It is worth mentioning that the Byzantine emperor Alexis Komnin advised the leaders of the crusade to allay with the Fatimids ${ }^{47}$ because they hate and hatred of the Seljuks and the Sunnis in general ${ }^{48}$. $\mathrm{Al}$ Afdal Al Fatimi ${ }^{49}$ had received a Byzantine delegation telling him to launch a crusade to extract the Levant from the Seljuks, he exhibited his pleasure to help the crusade. ${ }^{50}$

\subsection{Negotiations of the Crusaders with the Governor of Antioch "Yaghi Sian"}

The forces of Yaghi Sian, governor of Antioch, were exhausted from the many battles he had fought with the princes of the Levant, thus losing the ability to confront the Crusaders. Yaghi Siyan sought his neighbors from the Seljuk princes who ruled the cities of the Levant. They came to help him and attacked the Crusader forces besieged Antioch. In a battle near Albara ${ }^{51}$ in Muharram $491 \mathrm{AH}$ / December $1097 \mathrm{AD},{ }^{52}$ the Crusaders tried to escape from the strength of these Islamic forces using diplomatic methods and political negotiations ${ }^{53}$. They sent to Radwan - the governor of Damascus and Dokak - the governor of Aleppo - telling them that they only want Antioch and the country that was in the hands of the Byzantine Empire, and this was a trap for them in order not to face the Islamic forces in one front ${ }^{54}$. It is clear that the Seljuks did not stand idly in front of the Crusader invasion, but tried to defend the Islamic cities, and tried to unite and worked with the princes of the Levant to confront the Crusaders. ${ }^{55}$

Antioch persisted in its steadfastness, especially as Karbuga ${ }^{56}$ (the ruler of Mosul) ${ }^{57}$ marched to help them break the siege. The Crusaders' word was dispersed and some of them withdrew. There were

\footnotetext{
${ }^{42}$ Ibn al-Atheer, al-Kamil (part 8/416); Al Souri, the Crusades (part 1/ 305); Tawfiq, Islamic diplomacy (page 60), Kaseem the Crusade (page 105); Ali and Abbas; Diplomacy in the Age of the Crusades (page 4).

43 Todipod: Tareekh Al Rehla (page 167),Ta'a, Crusader Fatimid relations (page 98); Mutawi, the Crusades (page 52); Sheikh, Crusader Age (page 144).

${ }^{44}$ Abo Saed, The Islamic front (page 102/103).

${ }^{45}$ Gawanema, Peace Treaties (page 7-8).

${ }^{46}$ Ibn al-Atheer, al-Kamil (part 7/121), Zaborov, Crusaders in the East (page 88) Al-Zubai, The Arab Resistance (page 64-66); Al-Mutawi, The Crusades (page 52), Abu Said, Islamic Front (page 102-103).

${ }^{47}$ Renseman, History of the Crusades (part 1 / 343).

${ }^{48}$ Zamali, The Influence of the Internal Movements (page 139), Ganzuri, Roman attacks (page 190).

49 Al-Afzal Shahnasha Badr al-Din al-Jamali: Minister of the Fatimid State in the period 486-514 BC / $1094-$ 1121 AD. Ibn Al Emad, Shatharat Al Dahab. (part 6 / 128).

${ }^{50}$ Maalouf, The Crusades (page 69), Al Matwee, Crusades (page 35), Ali and Abbas, Diplomacy in the Age of the Crusades (page 4).

${ }^{51}$ Bara: A small town in the heart of Aleppo with a fort and orchards. Yakoot, Dictionary of Countries (part 1/ 320).

52 Ibn al-Qulansi, Thail (page 131-132), Ibn al-'Adim, Zobdat Halab (page 237), Ashour, The Crusade (part 1/ 188-189), Parker, The Crusades (page 34) Todipod, Tareekh Al Rehla (page 135), Zaborov, Crusaders in the East (page 84).

${ }_{53}$ Abu Said, Islamic Front (page 103).

${ }^{54}$ Ibn al-Atheer, al-Kamil (part 7/121), Zaborov, Crusaders in the East (page 84), Awad, The Crusades (Page 75).

55 Ta'a Al Matwee, The Crusade (Page 52); Sheikh, The Age of the Crusades (page 134-137); Zian, The Conflict between the Islamic Powers (page 53-56).

${ }^{56}$ Karbuga: Amir Turkmani, the rule of Mosul, 489 NC / 1096 AD, who took up the education of Imad Eddin Zanki, died 495 BC / 1101 AD. Ibn Al Wardi, history (part 2/9-10).
} 
sharp differences between the Byzantine delegate and the Crusader leader Bouhmand ${ }^{58}$.This because according to the agreement with the Byzantine Emperor and the front leaders, Antioch belongs to the Byzantine state, because it was under their control before Muslims conquest it; while Bouhmand aspired that Antioch would be for him, not shared by neither the Byzantine emperor nor any of the Crusader leaders. Buhamand accused the Byzantine delegate of secretly negotiating the Antioch protector of Islam without telling the crusade in order to reach a separate agreement with them as the Byzantines did before that when they sieged Nicaea. The Byzantine delegate felt the intention of the Crusaders to betray him, so he secretly fled and returned to his country. ${ }^{59}$

It is clear from the foregoing that the annulment of covenants, covenants and treaties is a consistent strategy in Crusader political thought, not only with their Muslim enemies, but even with their Byzantine allies. It will become clear to us in the following lines that they also betray their Fatimid allies and give no consideration to the agreements made with them. They get back to the negotiations and treaties in order to achieve their interests only. If the circumstances change in their favor, and they could dispense with their allies, or if their interests conflicted with the interests of their allies, they do not hesitate to break these alliances.

One of the Armenians ${ }^{60}$ in Antioch called "Fairuz" contacted with the crusader leader Bouhmand, and secretly negotiated with him to help him occupy the city by opening one of its towers. This happened when the city fell as a result of this betrayal in Rajab, 491 BC June 1098 AD, and they committed a terrible massacre. The fall of Antioch was a lifeline for the Crusader forces because the Islamic forces led by Karbuga went to save Antioch. ${ }^{61}$

It is clear that Buhmand was unable to occupy the city by forcing its protector to surrender during negotiations with them. He could not break into the city and forcibly overthrow it, but succeeded in conquering it by negotiating with one of the Armenian Christians inside the city and agreeing with him to facilitate the entry of Crusader forces from one of the towers which the Armenian guard. Buhmand's negotiations were not the only option with the Islamic garrison, but negotiated with the Armenian soldier and encouraged him to betray Muslims, relying on the association of faith that links the Armenians with the Crusaders.

\section{Negotiations of the Crusaders With "Karboga" Governor of Mosul}

Karboga forces arrived at Antioch and besieged the Crusaders who were inside it. So, the Crusaders sent him a delegation to negotiate with him. They offered him to hand over the city to him in return for their safe exit. He refused their request except by the sword, knowing that this novel is doubtful. Al Souri mentioned that the Crusaders offered to Karboga to break the siege of Antioch and leave it; or to prepare to fight. The battle broke out among them and the Muslims were defeated as a result of poor planning for the battle, and because the Crusader leaders used a style of religious tricks to motivate their soldiers to settle in the fighting. ${ }^{62}$

\footnotetext{
${ }^{57}$ Mosul: A city in northwestern Iraq, with its western gateway to Khorasan and Central Asia. Yakoot, Dictionary of Countries (part 5/223).

${ }^{58}$ Bohmend I: a European military commander took over the city of Trento Italian, and after his participation in the first crusade he took the rule of Antioch since the occupation until his death in 504 BC / 1111 AD. Durant, The Story of Civilization (part 15/21).

${ }^{59} \mathrm{Ibn}$ al-Qulansi, Thail (Page 135), Ibn al-Atheer, Al Kamel (part 7/120), Ibn Al Adeem, Zobdat Halab (Page 239), Abu Al-Fidaa, Al Mokhtasar (part 2 / 210), Nuweiri, Nehayat Al Arb (part 28 / 248-252), Aldwadar, Kanz Al Dorar (part 6/449), Ibn Katheer, beginning and end (part 12/191), Ibn Khaldun, History (part 4/85), Abu al-Mahasin, the shining stars (part 5/161), Mayer, History of the Crusades (part 1/ 103), Zaborov, Crusaders in the East (page 90-92).

${ }^{60}$ Armenians: A people living in Armenia and the surrounding countries such as the Caucasus, Azerbaijan and Iran. There is also a small percentage in the Levant and Egypt. They adopt Christianity on their own doctrine, and are closer to the Catholic Orthodox. Al Estakhry,Al Masalek Wa Al Mamalek (page 188-195).

${ }^{61}$ Ibn al-Atheer, Al Kamel (part 7/120), Ibn Al Adeem, Zobdat Halab (Page 239), Abu Al-Fidaa, Al Mokhtasar (part 2 / 210), Nuweiri, Nehayat Al Arb (part 28 / 248-252), Aldwadar, Kanz Al Dorar (part 6/449), Ibn Katheer, beginning and end (part 12/191), Ibn Khaldun, History (part 4/85), Mayer, History of the Crusades (part 1/ 103), Zaborov, Crusaders in the East (page 90-92).

${ }^{62}$ Ibn al-Atheer, Al Kamel (part 7/122), Abu Al-Fidaa, Al Mokhtasar (part 2 / 211), Nuweiri, Nehayat Al Arb (part 28 / 253-255), Ibn Katheer, beginning and end (part 12/191), Ibn Khaldun, History (part 4/86),Al Souri, the Crusades(part 1-400/401), Ashoor, the Crusade (part 1/210), Zaborov, Crusaders in the East (page 97). Mayer, History of the Crusades (part 1/ 104-105).
} 
However, it seems that Karbuga and his army commanders underestimated the situation during the siege of Antioch and during the negotiations they held with the Crusaders trapped inside. Also the contempt in confronting them militarily, which led to the defeat of Muslims and the rising of morale of the Crusaders and their continuing to attack the Islamic cities and villages surrounding Antioch.

The Crusaders were in the worst conditions under their siege in Antioch, and during the shortage of supplies and weapons and the interruption of the supplies from Crusader forces, and because of the occurrence of deep differences between the Byzantine representative and the leaders of the Crusader forces during the siege of Antioch. This made the representative of the Byzantine flee from the field because he was afraid from the assassination. If negotiations with the Crusaders were conducted more flexibly, the results would have been better.

\section{FifTH: NEGOtIATIONS DURING THE CRUSADE TO JERUSALEM}

Crusader forces launched from Antioch towards the south across the Shaman cities and villages on their way to Jerusalem, during this process the crusaders negotiated with Muslims, the most important of these negotiations are:

\subsection{Negotiations of the Crusaders with the Princes of the Levant}

The Crusaders besieged Ma'arat al-Nu'man, ${ }^{63}$ and tightened the siege on its surroundings, and entered into negotiations with its protector. It was agreed to grant safety to its people in return for surrender. After the Crusaders entered the city, they betrayed its people and committed a great massacre against them in Muharram, $492 \mathrm{BC}$

December 1098 AD. ${ }^{64}$ The Crusader leaders do not pay any attention to any treaty or security they give to any Muslim. This talks about the political barbarity and the lack of the simplest principles of human civilization and political ethics.

Crusader forces emerged under the command of the Crusader leader Raymond ${ }^{65}$ from Ma'arat alNu'man heading towards Jerusalem, where he took the internal road. He went down to Kafr Tab ${ }^{66}$, and there the princes of the Levant realized their weakness after their defeat in Antioch, and they failed to resist the crusaders. They followed the policy of negotiations to negotiate with them. ${ }^{67}$

Saheb shezer sent Sultan bin Monqith to the crusaders promising them not to reject their way when they break his borders; telling them that he will offer them all what they need from food to . Raymond agreed and sent Ibn Monqith to guide them in crossing the river of Al-Assi ${ }^{68}$ to the cities of South Sham. The Prince of Homs Ganah Al Dawla Ibn Malaeb sent to the Franks men carrying precious gifts, while they were in the fortress of the Kurds, ${ }^{69}$ and pledged to offer money and food to them provided that they won't harm him. The Kurds accepted .In their way to Tripoli, they passed though the city of Musyaf. ${ }^{70}$ Her Arab prince, holding an agreement with them in which the Crusader avoids

\footnotetext{
${ }^{63}$ Ma'arat al-Nu'man: A large old city of Homs, allowed between Aleppo and Hama. Sapphire, Dictionary of Countries, (Part 5/156).

${ }^{64}$ Ibn al-Qulansi, thail (page 136); Abu al-Fida, history (part 2/183); al-Dawadar, kanz al-Dirar (part 6/452);Ibn Khaldun, History (Part 4/86); Al-Shatri, History of the Campaign (page 68) ; Todibud, History of the Journey (page261); Meyer, History of the Crusades (part 1/107); Zaborov, Crusaders in the East (p. 111).

65 Raymond Sangili: Conte Toluz was experienced in the war of Muslims in Andalusia and died in $498 \mathrm{AH}$ before succeeding in the occupation of Tripoli. History of Islam (Part 51-33); Durant,The Story of Civilization (Part 15/21).

${ }^{66}$ Kafr Tab: It is a town 12 miles from Ma'arat al-Nu'man, where it lies between Aleppo and Aleppo. Sapphire, Dictionary of Countries, (part 4/740).

${ }^{67}$ Al Souri, the Crusades (part 2 / 41-42); Al Sheikh, Muhammad: The Age of the Crusades (p. 155);Guanmeh, Treaties of Reconciliation (page 16-17); zian, The Conflict between the Islamic Forces (page 9 / 157-158).

${ }^{68}$ Al-Assi River: It is a river that flows from the west of the Levant and is southward and flows into the Mediterranean Sea. It is one of the most famous rivers, and its rivers are characterized by high fertility. Ansari, Nokhbat Al Dahr (page 122);Al Suwaidi, Al-Nafha Al-Maskiya (page 45).

${ }^{69}$ Fortress of the Kurds: It is a fortress between Baalbek and Homs, and some of the princes of the Levant built a tower in its place and made some of the Kurds, and gave them a livelihood. Yakoot, Dictionary of Countries, (part 2/264); Zaki, Castles (page 64, 72).

${ }^{70}$ Musayaf: It is a fortress on the coast of the Levant near Tripoli, also called Masayab. Yakoot, Dictionary of Countries, (Part 5/144).
} 
to attack his country in return for money and supplies to them. They went to Bareen ${ }^{71}$ and then to the fortress of the Kurds, where the Crusaders seized it, and when the Crusader forces were on the way to the south, Prince of Tripoli Fkher Al Molouk Ibn Ammar sent his messengers, and pledged to pay to them. He also raised their flags on the walls of the city as a sign of loyalty to them. The Crusaders sent their messengers to Ibn Ammar to agree on the conditions, and their messengers noted the richness of Tripoli, so they decided to increase the agreed amounts by pressing him with the siege of the city of Arqa ${ }^{72}$ that follow Tripoli and then seized Antartos ${ }^{73}$ after its siege. ${ }^{74}$

It is clear from the above the extent of the bad image of the political map of the Levant in that period, the princes of the Islamic cities of Sham compete to satisfy the Crusader occupiers, and do not try to deal with this brutal occupation, and do not go to lift the siege of the Muslim cities besieged by the Crusaders. They look at the massacres committed over the people of Nu'man other people from the cities and villages of Sham. These princes initiates to open channels to negotiate with these criminal invaders to provide their loyalties and pay tribute to them, and also provide them with supplies and guides to help them on their Muslim brothers. That leadership was not at the level of responsibility, they are closer to the robbers and feudalists to be princes of the Islamic cities and the mandates of the affairs of Muslim people, they betrayed the secretariat that was entrusted to them. History will remember them of their betrayal and generations will not mercy them, and the blood of Muslims who shed, and the symptoms of Muslims violated by the Crusaders invaders will stay in necks of the princes, and they will be asked about this in front of Allah. Despite their betrayal, but the Crusaders' ambitions were greater than those of the downtrodden princes expected. The subsequent events proved that the Crusaders did not respect their covenants and agreements with them and betrayed them. This is the debt of the occupiers with traitors and agents who prefer their interests over the interests of their nation, their religion and their peoples.

\subsection{Negotiations to Invade Palestine between the Crusaders and the Fatimids}

Continuing the implementation of the Fatimid-Crusader agreement, the Fatimids attacked Bayt alMaqdis in Sha'ban 491 AH (August 1949 AD), where they destroyed its Seljuk protectorand controlled it and Eftekhar Al Dawla ${ }^{75}$ was its governor. ${ }^{76}$

During the siege of Antartus, an embassy of the Fatimid arrived at the Crusaders they welcomed them as small groups visiting Jerusalem, ranging from 200 to 300 unarmed, then they returned home peacefully, but the Crusaders rejected the Fatimid offer considered it as an insult to them. The Crusaders revealed their real objectives behind their rejection proposing new conditions on the Fatimids:

- That the Fatimids would hand over Jerusalem and its surrounding cities and villages to the Crusaders.

- The Fatimids should help the Crusaders to eliminate the remaining influence of the Seljuks.

- The churches built by Christians in the Levant are subject to the rule of the Crusaders. ${ }^{77}$

\footnotetext{
${ }^{71}$ Bareen: A blade between Homs and the coast, and its name is Barin. Yakoot, Dictionary of Countries, (Part $1 / 452)$

${ }^{72}$ Arqa: It is a town in the east of Tripoli, with four of them, one of the cities of Damascus, about a mile from the sea. It is located at the foot of a mountain. Yakoot, Dictionary of Countries (Part 4/109).

${ }^{73}$ Antartos: It is a country from the shores of the Levant, and is the last work of Damascus coastal, and the first work of Homs, and has two towers Hmsinan two blocks. Yakoot, Dictionary of Countries (Part 1/270).

${ }^{74}$ Abu al-Fida, al-Mokhtasar, (part 2/216); Aldwadar, Kanz Al dorar (part 6/472);Ibn Khaldun, History (Part 4/86); Guanmeh, Treaties of Reconciliation (page 17); Ashour, The Crusade, (Part 1/230); Mayer, History of the Crusades (part1/109); Zaborov,Crusaders in the East (p. 119).

${ }^{75}$ Eftekhar Al Dawla: He was one of the leaders of the Fatimid state during the reign of the caliph al-Mustali, and served in several locations, including Damascus and Beit al-Maqdis. Ibn Khaldun, History (Part 5/184); Abu Al-Mahasin, The Bright Stars (Part 5/148).

${ }^{76}$ Ibn al-Atheer, Al Kamel (part 7/12), Abu al-Fida, Al Mokhtasar, (part 2/211); Al Dwadar, Kanz Al dorar (part 6/450);Ibn Khaldun, History (Part 4/86).

${ }^{77}$ Abu al-Fidaa, Al Mokhtasar (Part 2/211); Al Souri, the Crusades, (part 2/ 56-57); Mayer, History of the Crusades (part 1/109);Zaborov, Crusaders in the East (page 119).
} 
The Fatimids received the Crusader's rejection of the proposals of their embassy and their march to occupy Jerusalem. They suffered a great shock, and all their intentions changed and their dreams and illusions that they built in their imaginations began to dissipate. ${ }^{78}$

The Crusaders completed their march towards Jerusalem, where they arrived in the city of Jibla ${ }^{79}$, and were within the property of Ibn Ammar, but its ruler the Judge Abu Mahmoud Abdullah bin Mansour ${ }^{80}$ was able to independence, and declare his subordination to the Fatimids, and when the Franks besieged it, the judge came out, and agreed with them to pay to them a sum of money and a number of horses ${ }^{81}$. Then the Franks left Tripoli, guided by ibn Ammar, and they arrived in Beirut, ${ }^{82}$ and the people of Beirut offered the money to them in return for not being subjected to their farms and in return to follow them. The same happened with Sidon ${ }^{83}$ and Acre ${ }^{84}$ and most of the Shami cities on their way. ${ }^{85}$

The surrender of the mentioned cities is due to the non resistance of the Fatimids to the Crusader invasion even after they known the intentions of the Crusaders to them, which made the cities of the Levant follow Tripoli and subordinate to the Crusaders and supply them with food and supplies to prevent their evil, ${ }^{86}$ and it is noteworthy that the Fatimids did not receive support from the local Sham residents because they hate them, and because of what the Fatimids left of injustice, hatred and hateful in the hearts of the people of the Levant except for the Shiite communities that supported the Fatimids in oppressing and conquering the people of cities known to adhere to the Sunni doctrine. ${ }^{87}$

The Crusaders arrived at Ramleh ${ }^{88}$ and Lod ${ }^{89}$, and occupied them easily, without fighting and without negotiations, the inhabitants left as soon as they heard the Crusaders' march on them. ${ }^{90}$ It is clear from the fall of Ramleh and Lod that the city and its inhabitants were in a condition of terror and weakness, by evicting their homes and citizens without negotiations. Because they didn't trust the Crusaders, or even trust their covenants. The cities of Sham negotiated the Crusader forces to surrender in return for safety, but the Crusaders betrayed the people of cities after their fall.

The city of Jerusalem was the largest city in Palestine. The crusaders surrounded it and managed to enter it on 23 Sha'ban 492 BC / July 15, 1099 AD, after a siege of forty days. They committed a terrible massacre in it. ${ }^{91}$

Ranseman said that the reason for the lack of stable diplomatic and political relations between the Muslim rulers and the Crusaders is the abhorrent anniversary of the massacre ${ }^{92}$. Eftekhar Al Dawla-

\footnotetext{
${ }^{78}$ Abu al-Fidaa, Al Mokhtasar (Part 2/211); Al Souri, the Crusades, (part 2 / 56-57);Ta'a, Fatimid Crusader Relations (page 111);Zamali, The Effect of Inner Movements (page 139);Mayer, History of the Crusades (part 1/109);Zaborov, Crusaders in the East(page119).

79 Jibla: A famous castle in the coast of the Levant, and is one of the works of Aleppo, located near Latakia. Sapphire, Dictionary of Countries (Part 2/105).

${ }^{80}$ Abdullah bin Mansour: Known as Ibn of Salihah, who took over the judiciary and the command of jurists in the fortress of Jiblah, and had extensive military experience. Ibn Khaldun, The Complete (Part 8/447).

81 Al Souri; The Crusades (Part 2/51);Al Shatri, Campaign History (page 68); Guanmeh, Treaties of Reconciliation (page 17).

${ }^{82}$ Beirut: It is a coastal city overlooking the Mediterranean Sea, with a commercial port. It was considered one of the works of Damascus, the origin of many Muslim scholars. Yakoot, Dictionary of Countries (Part 1/525).

${ }^{83}$ Sidon: A city located on the coast of the Levant, and one of the works of Damascus. Yakoot, Dictionary of Countries (Part 3/437).

${ }^{84}$ Acre: A city and port fortified on the coast of the Levant, known for its natural beauty and the importance of its strategic location. Yakoot, Dictionary of Countries (Part 4/143).

${ }^{85}$ Al Dawader; Kanz Al Dorar (part 6/474-477); Ibn Khaldun; History ( part 4/88), Al Souri, the Crusades, (part 2 / 63-65).

${ }^{86}$ Ghawanmeh, Treaties of Reconciliation (page 18).

${ }^{87}$ Bridge, History of the Crusades (page 98).

${ }^{88}$ Ramla: A city located in the center of Palestine west of Jerusalem, characterized as a purely Islamic city, built in the Umayyad era, and had a wall surrounding it. Yakoot, Dictionary of Countries (Part 3/69); Abu al-Fida, Takweem Al Boldan (p. 241).

89 Lod: A village located in Palestine west of Jerusalem. Yakoot, Dictionary of Countries (Part 5/15).

${ }^{90}$ Renseman, History of the Crusades (Part 1/412); Mayer, History of the Crusades (part 1/109).

91 Al Dawadar, Kanz Al Dorar (part 6/452); Ibn Khaldun, History (Part 4/86); Rimondagel, the history of the campaign (page 247); Meyer, History of the Crusades (part 1/111).
} 
the Fatimid governor of the city - has fortified him and 500 of his soldiers in the niche of David for three days, and they went to Ashkelon ${ }^{93}$ after the Crusaders secured them their lives ${ }^{94}$, it was the only surviving group. ${ }^{95}$ The Crusaders did not betray them as they betrayed the protectors and people of the cities of Sham, some of which were mentioned during this research.

After the fall of Jerusalem, Nablus ${ }^{96}$ surrendered two weeks later ${ }^{97}$, and then most of the Palestinian cities were surrendered and subjugated to the Crusaders except for some coastal cities such as Tire ${ }^{98}$ and Ashkelon. There were some Fatimid efforts to preserve some strongholds in Palestine ${ }^{99}$. It is based on subjective and factional goals, and has no authentic Islamic dimensions to protect and defend Muslims, and to preserve the sanctities of Muslims against Crusader attacks.

Since the Crusaders took control of Jerusalem to change its Arab and Islamic identity and made it a Crusader city, it met the needs of the new people coming from Europe. They brought about radical changes in all aspects of life: political, social, demographic, cultural, religious, economic, urban and other. These changes were also over most of the cities they occupied and subjugated to their control. ${ }^{100}$

The Crusaders humiliated Muslims and insulted the Islamic sanctities. They converted the Dome of the Rock into a church and transformed the Al-Aqsa Mosque into houses inhabited by the Crusader pimps and a store of their weapons and equipment. The Marwani oratory ${ }^{101}$ was turned into stables for their horses and their animals. They called it Solaiman's stables. They also used it to store weapons. ${ }^{102}$

\section{Sixth: Treaties of EQUality and Partnership between Muslims and Crusaders in ORDER TO CREATE A SECURITY ENVIRONMENT FOR THE CRUSADER SETTLEMENTS}

Due to the Crusaders' need for stability, and because of the large number of Crusader attacks on the Damascus countryside and other areas, the Crusaders held several treaties with the surrounding Islamic Emirates to form a buffer zone between them and was known as specifications ranges from south Al Zarqa ${ }^{103}$ to the nourth of Yarmouk ${ }^{104}$ and Bekaa ${ }^{105}$. The Crusaders share the income of this

\footnotetext{
${ }^{92}$ History of the Crusades (part 1/405).

${ }^{93}$ Ashkelon: It is a city of the works of Palestine, and it is on the road between the Levant and Egypt. Yakoot, Dictionary of Countries (Part 4/122).

${ }^{94}$ Ibn Katheer, AL Bedaya wa Al Nehaya (Part 12/192); Abu Al Mahasin, AL Nojom Al Zahera (part 5/164); A Souri, the Crusades (part 2/126); Renseman, History of the Crusades (Part 1/425-426); Zaborov, Crusaders in the East (page 122).

${ }^{95}$ AL Matwe, Crusades (page 54); Qasim, the condition Crusades (page 106);Al Zobaie, Arab Resistance (page 100-103).

${ }^{96}$ Nablus: It is a famous Palestinian city, located between two mountains, and is far from Jerusalem. Yakoot, Dictionary of Countries (Part 5 / 148-149).

${ }^{97}$ Todipod: The History of the Journey (page 337); Al Souri, The Crusades (Part 2/163, 182).

${ }^{98}$ Tire: A famous city on the coast of the Sham sea, surrounded by seawater on three sides, which is a sea of Muslim sea.Yakoot, Dictionary of Countries (Part 3/433).

${ }^{99}$ Abu al-Fidaa, Al Mokhtasar (Part 2/214-217); Al Dwadar, Kanz Aldorar (Part 6/450); Ibn Khaldun, Al Moqadima (page 199); Abu al-Mahasin, Al Nojoom Al Zahera (part 5/167, 170); Al Souri, the Crusades (part 2 / 181-182); Ta'a, Fatimid Crusader relations (page 124-127); Qasim, the condition of the Crusades (page 110); Shorrab, Al Mada'n (part 6 / 94-95); Zaborov, the Crusaders in the East (page 129).

${ }^{100} \mathrm{Al}$ Nakr,Changes in Jerusalem Crusader Occupation Period (page 191).

${ }^{101}$ The Marwani oratory: Located below the southeast corner of Al-Aqsa Mosque. Shorrab, History of Al-Aqsa Mosque (page 12).

${ }^{102}$ Shorrab, history of Al Aqsa Mosque (Page 5); Joseph, Unity during the Crusader aggression (page 17); Al Nakr, changes in Jerusalem occupation Crusader period (Page 203, 215).

${ }^{103}$ Al-Zarqa: The location of the Sham near Ma'an, and in it many springs are mentioned with severity. AlBaghdadi, Marased Al Etla'a (part 2/622); Al-Suwaidi, Al-Nafha Al-Maskiya (page 291); Shorrab, Al Ma'alem Al Athareya (page 134).

${ }^{104}$ Yarmouk River: It is a river on the border between Jordan, Palestine and Syria. It is one of the largest tributaries of the Jordan River, and near it the battle of Yarmouk 15 BC / 636 AD occurred between the Muslims and the Romans. Shorrab, the most famous monuments (page 297).

${ }_{105}$ Al Bekaa: A vast land between Damascus, Homs and Baalbek, with many villages and abundanwater. Andalusian, Mo'jam Ma Esta'jam (part 1/263); Yakoot, Mo'jam Al Bolan (Part 1/470);Al-Baghdadi, Marased Al Etla'a (Part 1/211).
} 
buffer zone with Damascus, and benefit from the grain storage and grazing livestock in the Golan ${ }^{106}$. The first of these treaties was mentioned by Ibn al-Qulansi between the crusader leader Sangil with the governor of Tripoli Fakhr al-Malukim ibn Ammar in 498 BC / 1104 AD during the Crusade ${ }^{107}$. The most important of these agreements: the Convention of the year $502 \mathrm{BC} / 1108 \mathrm{AD}$ between the governor of Jerusalem Crusader Baldwin I ${ }^{108}$ and Atabak ${ }^{109}$ Demashk Zahir Al Deen Tgtkin ${ }^{110}$, and repeated the agreement between the parties to expand the buffer zone in the year 503 BC / 1109 AD. 111

Such agreements are due to the weakness of the rulers of Damascus and other rulers of the Levant and their inability to defend the borders of their emirates. The Crusader government of Jerusalem also paid great attention to the establishment of markets and the promotion of the crusader trade movement in order to provide the living elements and sources of income for the nascent Crusader entities. ${ }^{112}$

\section{Seventh: Strategies of Muslims and Crusaders in CONDUCTING NEgotiations}

The negotiations conducted by both the Muslims and the Crusaders were not random, but were studying and following certain strategies to achieve their respective objectives:

\subsection{Strategies of Muslims in Negotiations at the Crusader Invasion of the Levant}

The Muslims followed confused policies in negotiating with the Crusaders, the most important are:

- The policy of falsification and closeness to the invading Crusader forces, and because of the fragmentation, fighting and conflict between their princes and the absence of religious clout to mobilize the fighting and push the invaders. ${ }^{113}$

- The Fatimids sought to strengthen on the Crusaders against the Seljuks, negotiate and agree with them on the division of the Levant after they were taken from the Seljuks. They were a poisoned dagger in the back of the Seljuk princes who came to defend the Levant, so the Crusaders betrayed them and break the covenant with them. ${ }^{114}$

- The interest of self-interest only, where the princes are interested in the basic maintenance of their interests and small emirates, while not marginalizing the efforts of the Seljuks in their attempts to break the siege of Antioch, and an attempt to recover from the Crusaders after the fall, but after their defeat in the Battle of Antioch, the strength of Muslims destroyed, including the religious and the Jihad. This is evident from the attitude of the Fatimid Eftekhar Al Dawla, the ruler of Jerusalem, who cared for the safe exit after the resistance of the Crusaders who betrayed his masters, leaving the city and its people to their fate under the swords of the invaders. ${ }^{115}$

\footnotetext{
${ }^{106}$ Al Golan: A mountainous area between Damascus, Tiberias and Horan. Andalusian, Mo'jam Ma Esta'jam (part 2/406); Al-Baghdadi, Marased Al Etla'a (Part 1/360); Al-Hamiri, Al-Rawad Al-Matar (page 183); Al Harbi, Mo'jam Al Ma'ajem (page 77).

107 Thail (page147).

${ }^{108}$ Baldwin I: one of the leaders of the first crusade and the founder of the Crusades of the Crusades, and the second kings of the Crusader Kingdom of Jerusalem ruled during 493-511 BC / 1100-1118 AD. Durant, The Story of Civilization (Part 1/23, 27).

${ }^{109}$ Atabak: The title is called the commander of the army, and in the Mamluk state is considered the most senior princes advanced after the deputy, and the term consists of "Ata" in the sense of the father and "bake" in the sense of Amir, in the term (Moraby Al Ameer), and called the Prince of the princes of the army (Atabak Al Askar). Amayra, the Mamluk Military Dictionary (page 14).

${ }^{110}$ Zahiruddin Tghtakin: Turkish military commander, founder of the government of the Bouryans, who ruled Damascus within the Seljuk state, took over Atabekia Damascus in 497 BC / 1104 AD, and died in 522 AH / 1128 AD. History of Islam (Part 33/41).

${ }_{111}$ Al Souri, the Crusades (part 2 / 844); Ibn al-Qulansi, thail (264, 273);Mayer, History of the Crusades (part 1/117).

112 Al Naker, Changes in Jerusalem Crusader Occupation Period (page 202).

${ }^{113}$ Al Souri, the Crusades (part 2 / 41-42);Sheikh Mohammed: the era of the Crusades (page 155); Ghawanmeh, treaties of Reconciliation (page 16-17).

${ }^{114}$ Todipod: Tareekh Al Rehla (page 167);Ta'a, Fatimid Crusader relations (page 98); Al Matwe, the Crusades (Page 52); Sheikh, the era of the Crusades (Page 144);Abu Said, Islamic Front (page 102-103).

${ }_{115}$ Abu al-Fidaa, Al Mokhtasar (Part 2/216); Al Dwadar, Kanz Aldorar (Part 6/472); Ibn Khaldun, History (part4/86); Remondagel ,The History of the Crusade (page 215); Meyer,History of the Crusades (part 1/109), Zaborov, the Crusaders in the East (page 129).Guanmeh, Treaties of Reconciliation (page 17); Ashour, The Crusade, (Part 1/230).
} 
- The initiative to seek reconciliation, and payment of funds, and supply the Crusader invaders with what they need supplies, food and equipments, but the disastrous that Ibn Ammar, the Fatimid ruler of Tripoli, provided the Crusaders with guides to guide them the way to Jerusalem. ${ }^{116}$

\subsection{The Strategy of the Crusaders during the Negotiations at the Crusader Invasion of the} Levant

The Crusaders followed dirty methods in negotiating with the Muslims of the region, reaching their goals with the lowest possible prices. The most important of these methods are:

- The imposition of the siege, choking, and the raising of panic and awe, and cut supplies from the cities and fortresses that they besiege and control. ${ }^{117}$

- The attempt to neutralize the forces surrounding the besieged city, and not to confront the Muslims united, ${ }^{118}$ Examples of this: that the Crusaders sent to - Dadaq and Radwan governor of Aleppo and Damascus - apostles during the siege of Antioch, tell them that their country is not an object of the Crusaders. They want the country which was in the hand of the Romans, so that they would not be sent to the rescue of Antioch. ${ }^{119}$

- To subjugate the cities by the power of sword except emergency situations in which they are defeated or delayed the confrontation with them. They negotiate and make treaties with them, and the purpose of ensuring the determination is that the Islamic cities are subject to looting and theft, and that their people and residents are subject to slaughter, murder, representation and massacres.

- Take advantages of enmity between Seljuks and the Fatimids in alliance with the Fatimids. This was the will of the Byzantine emperor before the start of their campaign from Constantinople to the depths of Asia Minor Seljuk. They received Fatimid delegations in Antioch and others during their siege to the cities of the Levant. They sent embassies to Cairo, capital of the Fatimid state, loaded with gifts. To complete the agreements and indeed benefited the Crusaders much of their alliance with the Fatimids, and the largest evidence is that the Fatimids took away the city of Jerusalem from the rulers who are loyal to the Seljuks, and if Jerusalem remained in the hands of the Al Arateqa, resistance would have been better. This applies to many cities and fortresses of the Levant. ${ }^{120}$

- Follow the policy of treachery: where the Crusaders give security to the Muslims in their cities to surrender, and after surrendering the sword begin in their bodies killing, fragmentation and representation,for example, what happened in Bara and Maara Nu'man. ${ }^{121}$

- Flexibility: like the consent of the Crusaders to the request to share the Levant, after the crisis in Antioch when, Karbuga governor of Mosul, besieged them and not rush to open the cities and villages that were on their way to Jerusalem. They accept negotiations with their rulers and accept their offers of funds and supplies. ${ }^{122}$

- And the alliance with the Christians of sham against the Muslim rulers of their cities, and these Christians played a major role in overthrowing these cities in the hands of the Crusader forces,

\footnotetext{
${ }^{116}$ Al Dwadar, Kanz Aldorar (Part 6/472); Ibn Khaldun, History (part4/86); Remondagel ,The History of the Crusade (page 215); Meyer,History of the Crusades (part 1/109), Zaborov, the Crusaders in the East (page 119).Guanmeh, Treaties of Reconciliation (page 17).

${ }_{117}$ Meyer,History of the Crusades (part 1/103), Zaborov, the Crusaders in the East (page 119). Qassem, the condition of the Crusades (page 104);Al Zubai, Arab resistance (Page 67).

${ }_{118}$ Abo saed, the Islamic Front (page 103)

${ }^{119} \mathrm{Ibn}$ Al Atheer, Al Kamel (part 7/121); Zabroov, the Crusaders in the East (page 119),Awad, The Crusades (page 75)

${ }_{120}$ Todipod: Tareekh Al Rehla (page 167);Ta'a, Fatimid Crusader relations (page 98);Al Matwe, the Crusades (Page 52); Abu Said, Islamic Front (page 102-103).

${ }^{121}$ Al Dwadar, Kanz Aldorar (Part 6/452); Ibn Khaldun, History (part4/86); Al Shatri, Tareekh Al Rehla (page 68); Todipod: Tareekh Al Rehla (page 261); Abo Al Feda'a, History (part2/183); Meyer, History of the Crusades (part 1/107), Zaborov, the Crusaders in the East (page 111).

${ }^{122}$ Guanmeh, Treaties of Reconciliation (page 7-8);Abu Said, Islamic Front (page 102).
} 
and this happened in many cities including: Tal Basser, Tarsus, Antioch and Bethlehem 123, but the Christians themselves were initiating these contacts Dirty, and did not observe the sanctity of the country that embraced them and protected them for centuries. 124

- Take control of the castles and establish new castles during their incursion into the Levant to help them tighten their grip on the areas they control and the surrounding areas. These castles will help them gather information about the movements of the Muslim forces. This information is evidence of fighting and negotiating with the Muslims. ${ }^{125}$

\section{ReSUlts}

The study reached a number of results, the most important are:

- Palestine has a great religious status among Christians. These Christians were granted full religious and civil rights through successive Islamic covenants under the pact of Omar that Omar bin Al Khattab contracted with the Christians of Jerusalem when the city was opened.

- The first crusade of the East to occupy Palestine under the pretext of protecting Christians, but the real reasons for the campaign lies in the political, economic and social factors that the European continent suffered in that era.

- Before the Crusader invasion, the Islamic countries in general and the Levant in particular were living in difficult conditions and suffering from internal divisions and weaknesses. These circumstances helped the success of the first Crusade in achieving its objectives.

- The Fatimid state initiated to negotiate with the Crusaders to achieve alliances against the Seljuks. In this way, the Fatimid state provided assistance to the Crusader forces. However, the Crusaders failed them and refused to tolerate them or give them any interests to benefit from.

- Most of the princes of the Levant negotiated with the Crusaders and got closer to them, paying tribute and offering the food and supplies in return for not attacking their country.

- After the occupation of the Crusaders of Palestine and around the country, they sought to open the door to negotiations with their Arab surroundings in order to normalize relations with them and provide the elements of life for their emerging entities, so they contracted treaties of equality and cooperation agreements with them.

- The crusader occupation followed a strategy of equality negotiations with the Islamic Emirates to create a security belt for the Crusader settlements, and provide the aspects of life for those settlements.

\section{REFERENCES}

[1] Ansari, Shams al-Din Abi Abdullah Mohammed Sufi Damascene. (1865).Nokhbat Al Daher fi Ajaeb Al Bar wa Al Bahr. (Care and corrected by: Atschas ibn Yahya). (Peterburg: Imperial Academy Press).

[2] Parker, Ernst. The Crusades. (Translated by: Al-Baz Al-Arini). Beirut: Arab Renaissance House.

[3] Bridges, Anthony. (1985). History of the Crusades. (Translated by: Ahmed Sabano and Nabil Al-Jeroudi). Damascus: Dar Qutaiba.

[4] Todipod, Peter. (1999). History of the Trip to Jerusalem (Translation and Commentary: Hussein Mohamed Attieh). Cairo: University Knowledge House.

[5] Tawfiq, Omar. (1986). Islamic diplomacy and peaceful relations with the Crusaders. (Alexandria: University Youth Foundation).

${ }^{123}$ Bethlehem: A Palestinian town near Jerusalem, characterized by its religious importance to the Christians of the birth of Jesus Christ and the presence of the Church of the Nativity, which is the destination of Christian pilgrims. Yakoot, Dictionary of Countries (Part 1/521).

${ }^{124}$ Ibn al-Qulansi, Thail (page 135), Ibn al-'Adim, Zobdat Halab (page 239), Al Nowairy, Nehayat Al Arb (part28/248-252); Ibn Khaldun, history (part4/85), Abo Al Mahasen, Al Nojoom Al Zahera (part5/161); Meyer, History of the Crusades (part 1/103), Zaborov, Crusaders in the East (page 84). Qassem, the condition of the Crusades (page 104);Al Zubai, Arab resistance (Page 67).

${ }^{125}$ Meyer, History of the Crusades (part 1/310), Awad, the Crusade (84); Al Zubai, Arab resistance (Page 8081),Zaki, Castles (page 49). 
[6] Ibn al-Atheer, Abu al-Hasan Ali ibn Abi al-Karam Muhammad ibn Muhammad ibn 'Abd al-Karim. (1997). Al Kamel fi Al tarekh. Investigation: Omar Abdel Salam Tadmari. Beirut: Arab Book House.

[7] Al-Janzouri, and Ali Abdul Samie. (2001). Roman naval attacks on the shores of Islamic Egypt in the Middle Ages. The history of the northern coast of Egypt through the ages. A working paper presented to the symposium held by the Committee of History and Archeology of the Supreme Council of Culture in collaboration with the Faculty of Arts, Alexandria University, 22-23 April 1998. (Cairo: Egyptian General Book Organization).

[8] Hussein, Athal Ibrahim. (2012). Some embassies of scientists in the era of the Crusades through the book of the history of Damascus to Ibn Assaker for the period (490-571BC / 1096-1175 AD). Tikrit University Journal of Humanities. 19 (10), 359-387.

[9] Hattit, Ahmed. (2003). Issues from the history of the Mamluk political and cultural. Beirut: Euphrates for Publishing and Distribution.

[10] Ibn Kharadahabah, Abu al-Qasim 'Ubaydullah bin Abdullah. (1889). Al Msalek wa Al Mamalek. (Beirut: Dar Sader).

[11] Ibn Khaldun, Abdul Rahman bin Mohammed bin Mohammed al-Hadrami Ashbaily. (1988).Dewan Al Mobtada wa Al Khabar fi Tareekh Al Arab wa Al Ajam wa Al Barbar wa man Asharahom min Thawy Al Soltan Al Akbar known as history of Ibn Khaldun. (Inquiry: Khalil Shehadeh). Beirut: Dar al-Fikr.

[12] Aldwadar, Abu Bakr bin Abdullah bin Aibek. (1961). Kanz Al Dorar and Jame Al Gharar. (Investigation: Mohammed Saleh Al-Munajjid, Said Abdel Fattah Ashourand others). Cairo: German Institute of Archeology.

[13] Durant, William James. (1988). The Story of Civilization. (Translated by: Zaki Naguib Mahmoud and others). Beirut: Dar Aljeel.

[14] Al Thahabi, Shams Eddin Abu Abdullah Mohammed bin Ahmed bin Othman bin Qaimaz. (1993). Tareekh Al Islam wa Wafiat Al Mashaheer wa Al Alam. (Investigation: Omar Abdel Salam al-Tadmari). Beirut: Arab Book House.

[15] Al Thahabi, Shams Eddin Abu Abdullah Mohammed bin Ahmed bin Othman bin Qaimaz. (1985). Seyar Al A'lam wa Al Nobala. (Investigation: Shoaib Arnaout and others). Dar Al-Resala Publishing.

[16] Renseman, Stephen. (1997). History of the Crusades. (Translated by: Al-Baz Al-Arini) Beirut: Culture House.

[17] Zaborov, Mikhail. (1986). Crusaders in the east. (Translated by: Elias Shahin). Moscow: Progress House.

[18] Zamili, Youssef Ibrahim. (1987). The influence of the internal movements in blocking the jihad against the crusaders (unpublished master thesis). Umm Al Qura University, Makkah.

[19] Zaki, Abdul Rahman. (1968). Castles in the Crusades. The Egyptian Historical Journal, 1 (15), 49-86.

[20] Zobaie, Mahmoud Fayyad. (2003). Arab Islamic resistance to the Crusader invasion until the battle of Hittin.(Ph.D) University of Baghdad, Baghdad.

[21] Zian, Hamed and Zian Ghanem. (1983). The political and military struggle between the Islamic forces during the Crusades. (Cairo: House of Culture for publication and distribution.

[22] Abu Said, Hamid Ghoneim. (2007). The Islamic Front in the face of the crusader plans. Cairo: Dar es Salaam.

[23] Suyuti, Abdul Rahman bin Abi Bakr. (1952). History of the Caliphs. Cairo: Al Sa'ada Press.

[24] Shatri, Fuchia. (1990). The history of the campaign to Jerusalem. (Translated by: Ziad Asali). Amman: Dar Al Shorouk.

[25] Shorrab, Mohamed Mohamed Hassan. (2006). Palestinian cities. Amman: Al Ahlia for Publishing and Distribution.

[26] Sheikh Mohammed Mohammed Morsi. (2004). The era of the Crusades in the East.

[27] Safadi, Salah al-Din Khalil bin Aibek bin Abdullah. (2000). Al Wafi bi Al Wafiat. (Investigation: Ahmed Arnaout and Turki Mustafa). (Beirut: Heritage Revival House).

[28] Al Souri, William. (1994). History of the Crusades. (Translated by: Hassan Habashi). Cairo: Egyptian General Book Organization.

[29] Ta'a, Amjad Hafez. (2012). Political and Military Relations between the Fatimids and the Crusaders in Egypt and the Levant (unpublished Master Thesis). Islamic University-Gaza, Palestine.

[30] Ashour, Said Abdel Fattah. (1964). New lights on the Crusades. (D. Cairo: Dar Al-Qalam.

[31] Ashour, Said Abdel Fattah. (2010). The crusade is a shining page from the history of the Arab Jihad in the Middle Ages. Cairo: The Anglo-Egyptian Library.

[32] Ibn al-Adeeem, Kamal al-Din ibn 'Umar ibn Ahmad ibn Hiba Allah ibn Abi Jarada al-Aqili. (1996). 
Zobdat Halab fi Tareekh Hlab. The putter of the footnotes: Khalil Mansour. Beirut: Scientific Book House.

[33] Attia, Hussein Mohamed. (2000). Studies in the history of the Crusades. Alexandria: Dar Al Maarifa University.

[34] Ali and Abbas. (2009). Diplomacy in the Age of the Crusades 491-589 BC/ 1097-1193 AD, Journal of the University of Kirkuk for Humanitarian Studies,4 (2), 1-10.

[35] Ibn al-Amad, Shahab al-Din Abi al-Falah 'Abd al-Hayy ibn Ahmad ibn al-Hanbali al-Dimashqi. (1986). Shatharat Al Dahab fi Akhbar Min Thahb. (Investigation and comment: Mohammed Arnaout). Damascus: Dar Ibn Katheer.

[36] Amayreh, Mohammed Abdullah Salem. (2011). The Mamluk Military Dictionary. Amman: Dar Knouz Knowledge for Publishing and Distribution.

[37] Awad, Mohamed Mounes Ahmed. (1999). Crusades historical and monetary studies. (Cairo: Dar Al Shorouk).

[38] Guanma, Yousef Darwish. (1995). Peace and peace treaties between Muslims and Frenj. Amman: Dar AlFikr.

[39] Abu al-Fida, Imad al-Din Isma'il ibn Ali ibn Muhammad ibn Muhammad ibn 'Umar ibn Shahnashah ibn Ayyub al-Muayyad, the owner of Hama.Al Mokhtasar fi Akhbar Al Bashar. Egyptian Husseiniya Press.

[40] Abu al-Fida,. History of Abu al-Fida.

[41] Abu al-Fida, (1840). Taqweem Al Boldan . (Correction: Raynod and Baron Mac Cookin Dyslan). Paris: Printing House Bowl.

[42] Ibn al-Qulansi, Abu Ya’li Hamza ibn Asad ibn Ali al-Tamimi al-Damasci. (1908). History of Damascus. (Beirut: Press of the Jesuit Fathers).

[43] Ibn Katheer, Abu al-Fida 'Isma'il ibn' Umar ibn Qatheer al-Qurashi al-Basri and then al-Dimashqi. (1988). Al Bedaya wa Al Nehaya. (Inquiry: Ali Chery). House of Heritage Revival.

[44] Kassem, Qasim Abdu. (1990).The condition of the crusade. Kuwait: National Council for Culture, Arts and Letters - World of Knowledge.

[45] Meyer, Hans Eberhard. (2008). History of the Crusades. (Translated by: Emad Eddin Ghanem), (1985).

[46] Al-Mutawi, Mohammed Al-Arousi. (1982). Crusades in the East and West. Dar al-Gharb al-Islami.

[47] Maalouf, Amin. (1998). Crusades as the Arabs saw them. (Translation: Afif Damascene). Damascus: Dar Al-Fikr.

[48] Abu al-Mahasen, Yousef bin Taghri Berdi bin Abdullah al-Dhahiri al-Hanafi. Al Nojoom Al Zahira fi Molok Masr wa Al Kahera. Cairo: Ministry of Culture and National Guidance.

[49] Al-Maqdisi, Abu Abdullah Muhammad ibn Ahmad al-Maqdisi al-Bishari. (1991). Ahsan Al Takaseem fi Ma'refat Al Akaleem. Beirut: Dar Sader.

[50] Al Naker, Mohamed Hafez. (2003). The administrative, urban and demographic changes in the city of Jerusalem during the period of the occupation of the French (Crusader) 492-583 BC / 1099-1187 AD. Al Manara Magazine. 9 (1), 191-218.

[51] Nuwairi, Shahabuddin Ahmed bin Abdul Wahab bin Mohammed bin Abdul Majid Al Qurashi. (2003). Nehayat Al Arb fi Fonon Al Adab. Cairo: National Library and Archives of Egypt.

[52] Ibn al-Wardi, Omar ibn Muzaffar ibn Umar ibn Muhammad ibn Abi al-Fawares al-Wardi al-Maari Al Kanadi. (1996). Tatma Al Mokhtasar fi Akhbar Al Bashar known as the history of Ibn Al Wardy. Beirut: Scientific Book House.

[53] Yaqoot, Shahabuddin Abu Abdullah Yacout bin Abdullah Al-Hamawi Al-Roumi. (1995). Mo'jam Al Boldan. Beirut: Dar Sader.

[54] Youssef, Joseph Nasim. (1981). Unity and movements of Arab vigilance during the Crusade. Beirut: Arab Renaissance House. 
AUTHOR'S BIOGRAPHY

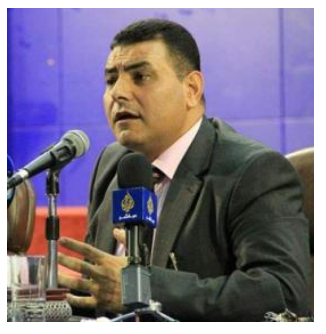

Dr. Ghassan Mahmoud Washah, A Palestinian historian with a number of published books and the head of the Department of History and Archeology at the Islamic University of Gaza. The President of the Center for Oral History at the former Islamic University and Chairman of the Board of Directors of the University of the Nation for Open Education and member of the Board of Directors of the Center for Palestinian History and Documentation. And a member of the International Federation of Historians. Member of the Union of Arab Historians in Cairo

Member of the Union of Arab Historians in Iraq and Vice-President of the Education Forum in Gaza

Former member of the Board of Directors of the Center for the Protection of Human Rights. He is the author of dozens of scholarly researches published in Arab and international journals. He has published dozens of scientific researches in English, ruled and published in India, Canada, the United States, the Netherlands and others.

Member of the Board of Directors of the Jerusalem Society for Studies and Research and Chairman of the Commission on Human Sciences

Member of the Board of Directors of Future Center for Studies and Research - Gaza. And a member of the editorial board of the historical magazine published by the Center for Palestinian History and Documentation and a member of the scientific board of Al-Quds for Studies and Research. Member of the scientific advisory board of the Journal of Social and Historical Studies in Nouakchott. Masters in History, Civilization and Human Rights. He has a clear presence in the Palestinian, Arab and international media, and presented a number of historical historical series through a number of satellite channels and radio stations. He participated in dozens of scientific conferences. And the work of the Chairman of a scientific committee for a number of them ruled dozens of scientific research for a number of magazines and conferences.

Citation: D. Ghassan Mahmoud Washah. "Negotiations between Muslims and Crusaders at the Crusader invasion of the Levant (489-492 BC/1096-1099 AD)”. International Journal of History and Cultural Studies (IJHCS). vol 4, no. 3, 2018, pp. 26-41. doi:DOI: http://dx.doi.org/ 10.20431/2454-7654.0403005.

Copyright: () 2018 Authors. This is an open-access article distributed under the terms of the Creative Commons Attribution License, which permits unrestricted use, distribution, and reproduction in any medium, provided the original author and source are credited. 